Manuale di linguistica friulana

MRL 3 


\section{Manuals of Romance Linguistics}

Manuels de linguistique romane Manuali di linguistica romanza Manuales de lingưística románica

Edited by

Günter Holtus and Fernando Sánchez Miret

\section{Volume 3}




\section{Manuale di}

linguistica friulana

\section{A cura di}

Sabine Heinemann e Luca Melchior

\section{DE GRUYTER}


ISBN 978-3-11-031059-7

e-ISBN (PDF) 978-3-11-031077-1

e-ISBN (EPUB) 978-3-11-039482-5

\section{Library of Congress Cataloging-in-Publication Data}

A CIP catalog record for this book has been applied for at the Library of Congress.

Bibliographic information published by the Deutsche Nationalbibliothek

The Deutsche Nationalbibliothek lists this publication in the Deutsche Nationalbibliografie; detailed bibliographic data are available on the Internet at http://dnb.dnb.de.

(c) 2015 Walter de Gruyter GmbH, Berlin/Boston

Cover-Bildnachweis: @ Marco2811/fotolia

Typesetting: jürgen ullrich typosatz, Nördlingen

Printing and binding: $\mathrm{CPI}$ books $\mathrm{GmbH}$, Leck

$\otimes$ Printed on acid-free paper

Printed in Germany

www.degruyter.com 